\title{
Male Blue Gourami (Trichogaster trichopterus) Nest-Building Behavior Is Affected by Other Males and Females
}

\author{
Gad Degani1,2*, Michael Bar Ziv1 \\ ${ }^{1}$ Faculty of Science and Technology, Tel-Hai Academic College, Tel Hai, Israel \\ ${ }^{2}$ MIGAL-Galilee Technology Center, Kiryat Shmona, Israel \\ Email: 'gad@migal.org.il, mb_z_c@hotmail.com
}

Received 18 April 2016; accepted 21 June 2016; published 24 June 2016

Copyright (C) 2016 by authors and Scientific Research Publishing Inc.

This work is licensed under the Creative Commons Attribution International License (CC BY).

http://creativecommons.org/licenses/by/4.0/

(c) (7)

\begin{abstract}
In this study, we examine male blue gourami (Trichogaster trichopterus) nest-building behavior that is affected by other males and interactions under experimental conditions. Males found in the area control the territory and sexual behavior, and are influenced by the behavior of other males. The results of this study show that the sexual behavior (nest-building) of male blue gourami is affected both by the behavior and pheromones of other males. We suggest that males must defend their territories in order to prevent these two factors from interfering in nest-building.
\end{abstract}

\section{Keywords}

Male Blue Gourami, Blue Gourami, Sexual Behavior and Pheromones

\section{Introduction}

Blue gourami belonging to the Labyrinthici suborder, which belongs to the Perciformes order, is characterized by the presence of a chamber, or labyrinth, above the gills for the retention of air for breathing [1]. The 16 known genera contain about 80 species distributed throughout most of southern Asia, India and central Africa [2]. In Labyrinthici, an air-filled breathing cavity known as the labyrinth is located above the gills under the operculum on top of the head behind the eyes. The blue gourami (Trichogaster trichopterus) or three-spot gourami is native to Malaysia and Thailand. The blue gourami gets its name from its basic blue coloring. The gourami has a touch of silver on its belly and even a slash of green on the tips of its gill covers and fins. This native

${ }^{*}$ Corresponding author.

How to cite this paper: Degani, G. and Ziv, M.B. (2016) Male Blue Gourami (Trichogaster trichopterus) Nest-Building Behavior Is Affected by Other Males and Females. Open Journal of Animal Sciences, 6, 195-201.

http://dx.doi.org/10.4236/ojas.2016.63025 
blue gourami also has two large black spots on its sides, with the eye making up the third spot (hence the name three-spot) [1]. The labyrinth is a circular spot of very wrinkled tissue that offers more surface area for oxygen intake. This cavity supplements the breathing function, since it is well suited to gaseous interchange [1]. Because of these accessory organs, anabantidae fishes can even survive in water with very little oxygen content. The males often become territorial and very protective of the nest. As the female prepares to lay her eggs, the male wraps himself around her, catches the eggs in his mouth and spits out the eggs into the nest. The bubbles give the fry the oxygen they need for their first stages of development. Common habitats include rice fields. Forselius [3] reviewed the behavior, systematics, distribution and biology of the anabantidae species.

Many aspects of growth reproduction and commercial production of the blue gourami are described in detail [4].

The blue gourami in particular exhibits a very complex social and spawning behavior, and because of this, it has become a common subject for ethological studies. Miller [5] described in detail the social and spawning behavior of the blue gourami. The literature contains other studies on the same subject [6]-[9]. The aggressive behavior that enhances the ability of male blue gourami to defend their territories in signaled contests is studied in detail [10]. In blue gourami, as in many other vertebrate species that exhibit resource defense polygyny, males establish their territories well in advance of the arrival of females and, thus, are able to defend them over a relatively long period of time [10].

In addition to the aggressive behavior of males found in the same area as the females, many other parameters affect the nest-building of male blue gourami. Temperature affects males in building nests under different conditions, and brain and pituitary gene expression related to reproduction and growth is described [11]. Males that are maintained under non-reproductive conditions do not build nests, and the gonado-somatic index (\% GSI) is significantly higher in fish maintained at $27^{\circ} \mathrm{C}$ compared to fish maintained at $23^{\circ} \mathrm{C}$. The relative mRNA levels of brain gonadotropin-releasing hormone 3 (GnRH3), pituitary adenylate cyclase-activating polypeptide (PACAP), insulin-like growth factor-1 (IGF-1), pituitary b-luteinizing hormone (bLH) and prolactin are significantly higher when the fish are maintained at $27^{\circ} \mathrm{C}$ than at $23^{\circ} \mathrm{C}$ or $31^{\circ} \mathrm{C} . \beta$-Follicle-stimulating hormone $(\beta \mathrm{FSH})$ mRNA levels were significantly lower when maintained at $31^{\circ} \mathrm{C}$ than at the other temperatures. Nests were observed only in males under reproductive conditions. In these fish, higher mRNA levels of GnRH3, PACAP, $\beta \mathrm{FSH}, \beta \mathrm{LH}$ and prolactin were detected at $27^{\circ} \mathrm{C}$, and higher mRNA levels of IGF- 1 were detected at $23^{\circ} \mathrm{C}$, when compared to other maintenance temperatures or with fish that did not build nests.

In conclusion, we propose that temperature has a greater effect on the transcription of genes associated with reproduction than on those pertaining to growth. The purpose of the present study was to examine the effect of males and females on nest-building blue gourami under experimental conditions [11]. Water of different salinities affected hormones involved in reproduction and male nest-building [12]. In non-reproductively active males, mRNA levels of brain gonadotropin releasing hormone 1 (GnRH1), pituitary $\beta$ FSH and prolactin (PRL) were significantly higher in males maintained in underground water. In reproductively active males, mRNA levels of brain GnRH1, GnRH3 and pituitary PRL were significantly higher than in males maintained in saline water. Thus, it is suggested that underground water having high levels of salinity and conductivity affects the gene expression of reproduction-related hormones; in reproductively active males, it shortened the duration of nest-building by blue gourami males [12]. Another very important parameter of interaction between males and females is that of pheromones [13]-[16].

A number of studies concerning chemical communication in Trichogaster trichopterus from the Belontiidae family indicate that this species may serve as a model for the whole systematic group [6] [8] [15]. An analysis by gas chromatography-mass spectrometry was performed to identify steroids and steroid glucuronides in gonads of $t$ blue gourami and in water in which the fish were maintained. Full mass spectra of estradiol-17fl (E2), testosterone, 17at-hydroxyprogesterone, cholesterol, stigmasterol, 4fl-methylcholesterol, estrone, 17at, 20flhydroxy-4-pregnen-3-one (17, 20-P) and sitosterol were obtained. The above-mentioned steroids were detected in both female and male gonads, with the exception of estrone, which was detected only in the male, and 17, 20-P, which was detected only in the female. All steroids except for 17, 20-P were detected in the water in which the fish were maintained [13].

It is well known that for blue gourami maintained in a group at high densities in different combinations (males, females and both sexes), no sexual behavior and nest-building occur.

The purpose of this study was to examine in more detail the effect of males and females on the nest-building of blue gourami male under experimental conditions. 


\section{Materials and Methods}

\subsection{Fish and Experimental Design}

Blue gourami fish (T. trichopterus, Perciformes, Osphronemidae), which were maintained and bred at MIGAL laboratories in northern Israel, were used in this study. The fish were kept in an aquarium $(50 \times 50 \times 30 \mathrm{~cm})$ at a temperature of $27^{\circ} \mathrm{C}$ from November to April under a light regime of $12 \mathrm{~h}$ light:12 h darkness [11] until the beginning of the experiments, and were fed an artificial diet (45\% protein, $7 \%$ fat), supplemented with frozen live food (Artemiasalina). All research involving the fish was approved by the committee in MIGAL dealing with animals and conforms to NIH guidelines. After an acclimation period of 10 days, the experiment was carried out on the fish for seven days. All the mature fish were weighed and measured before the experiments commenced. In each experiment, eight aquariums were used for the experiment and eight aquariums for control (number of replications) (Figure 1). Only the experiments for which the males built nests in the control groups were measured and are presented in the results.

Experiment 1. One blue gourami male was maintained in the aquarium for control, and two males (Figure 1(c)) were used in the experiments. The number of nest-building males (Figure 1(e) and Figure 1(f)) in the experimental and control aquariums was monitored.

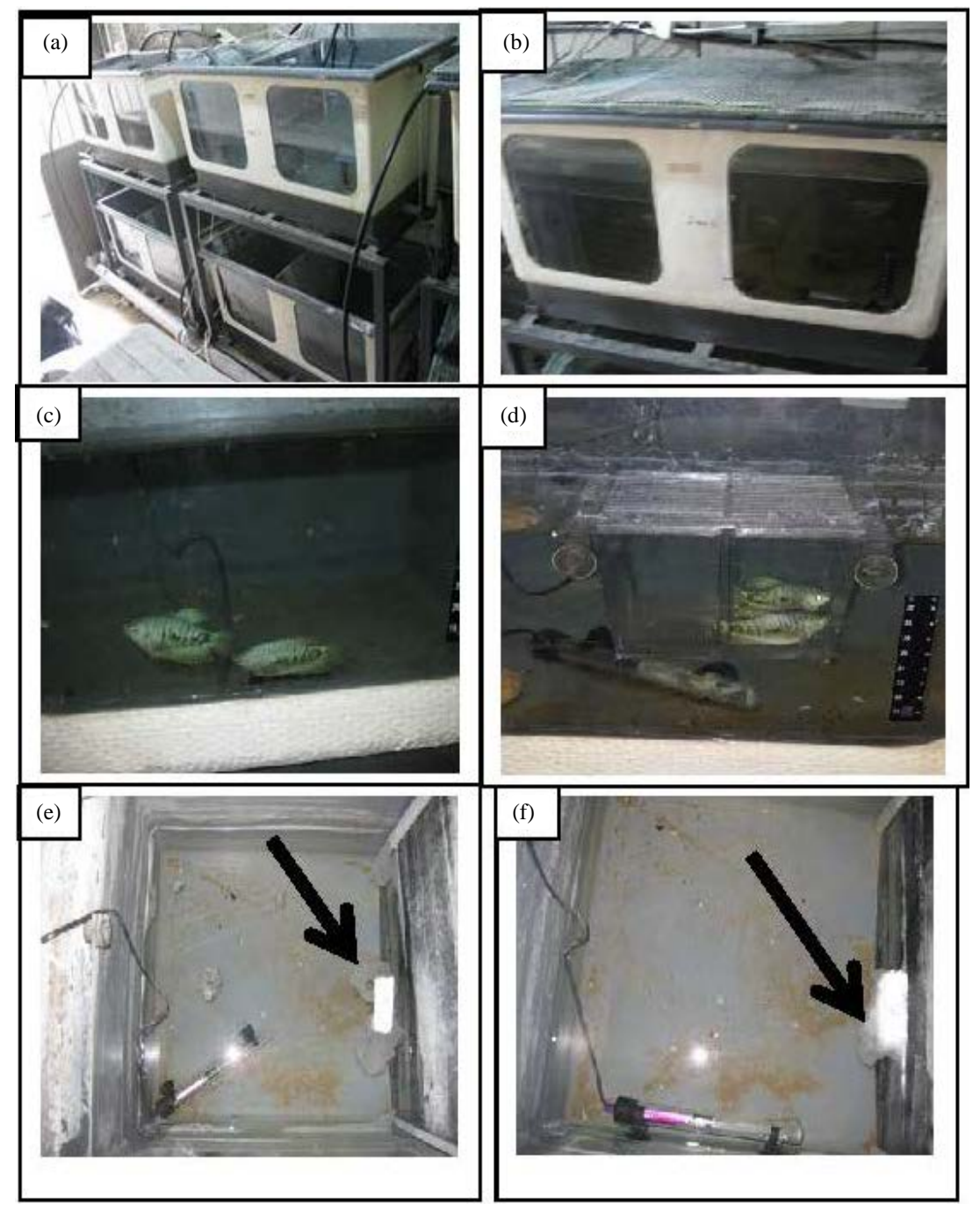

Figure 1. The experimental aquarium systems. (a) and (b) illustrate the aquarium systems; (c) shows two males in experiment 1 ; (d) shows two males in the cage in experiment 3; (e) and (f) illustrate male nest-building in the aquariums. 
Experiment 2. Three reproductively active blue gourami males were maintained in each experimental aquarium and the control group was the same as described in experiment 1 (one male maintained in the aquarium).

Experiment 3. One male was maintained in the experimental aquarium and two other males were maintained in the same aquarium in a small cage $(10 \times 15 \times 10 \mathrm{~cm})$ (Figure $1(\mathrm{~d}))$.

\subsection{Statistical Analysis}

A t-test was used in order to examine whether significant differences exist between the measurements (weight and length) of fish in the experimental and control groups. To compare the number of nest-building males in the experimental and control groups, we compared the results to random distributions using $\mathrm{X}^{2}$-test.

\section{Results}

No significant differences were found between the experimental and control groups using the t-test of weight and length measurements of fish in the three experiments in the present study (Table 1).

The two mature males maintained in the aquarium $(50 \times 50 \times 30 \mathrm{~cm})$ and the aquariums where nest-building occurred were monitored. There were no significant differences among the percentage of nest-building males in the experimental group (two males in one aquarium, $50 \%$ of males in the aquarium built nests) and the control group (one male in the aquarium, 62\% of males in the aquarium built nests) (Figure 2).

Table 1. Comparison between the measurements of fish in the experimental and control groups in the present study.

\begin{tabular}{cccc}
\hline Experiment Number & Number of Replications & Mean Weight (g) \pm SD & Mean Length (cm) \pm SD \\
\hline Experiment 1 & 8 & $8.0 \pm 2.6$ & $7.85 \pm 0.4$ \\
Control 1 & 8 & $7.5 \pm 2.5$ & $7.8 \pm 0.4$ \\
P (Test) & & $\mathrm{P}=0.9>0.05$ & $\mathrm{P}=0.7>0.05$ \\
Experiment 2 & 8 & $10.3 \pm 3.5$ & $7.9 \pm 0.4$ \\
Control 2 & 8 & $10.0 \pm 2.6$ & $7.8 \pm 0.5$ \\
P (Test) & & $\mathrm{P}=0.8>0.05$ & $0.8>0.05$ \\
Experiment 3 & 8 & $10.2 \pm 2.4$ & $8.4 \pm 0.5$ \\
Control 3 & 8 & $10.6 \pm 4.1$ & $8.4 \pm 0.6$ \\
P (Test) & & $\mathrm{P}=0.5>0.05$ & $\mathrm{P}=0.5>0.05$ \\
\hline
\end{tabular}

\section{$\%$ nest-building}

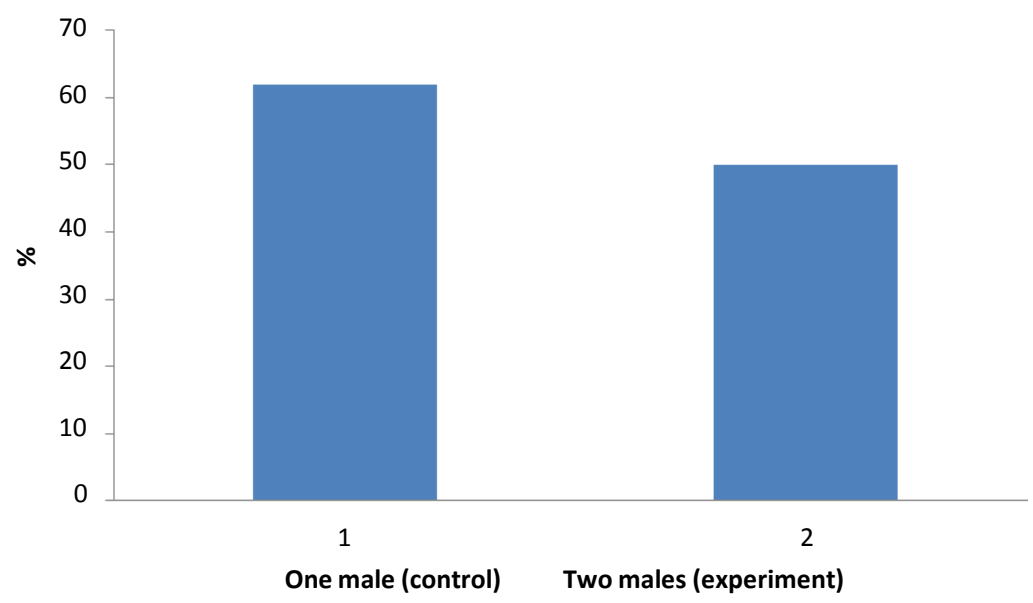

Figure 2. Comparison between the \% of nest-building in the aquariums in the experimental group where two males were held in the aquarium (number of aquarium $=8$ ) and the control group where one male was held in the aquarium (number of aquarium $=8$ ). No significant differences were found $\left(\mathrm{X}^{2}\right.$-Test, $\mathrm{P}>$ 0.05). 
On the other hand, nest-building was significantly reduced to $25 \%$ where three males were maintained in one aquarium in the experimental group compared to $50 \%$ in the control. Significant differences exist between the control group (one male maintained in one aquarium) compared to the experimental group (three males maintained in one aquarium) (Figure 3).

Similar results were found in the next experiment where three males were maintained in the aquarium but two were held in the cage (Figure 4 and Figure 5) or three females were maintained with one male. The percentage of nest-building was significantly less (25\%) compared to the control group (75\%) in the aquariums where nest-build activity took place (Figure 4).

\section{$\%$ nest-building}

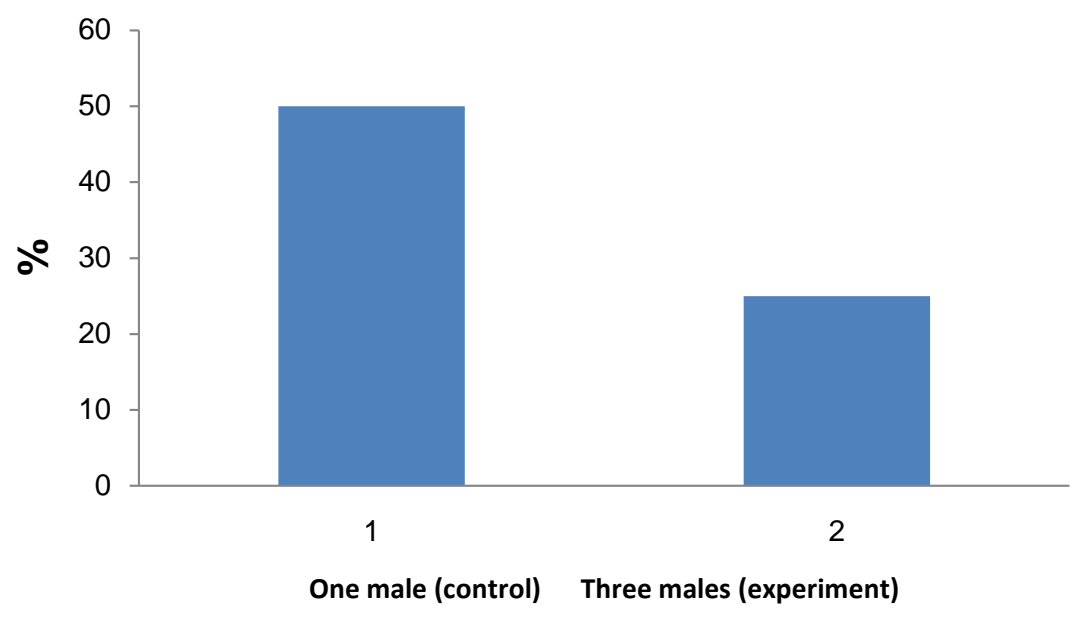

Figure 3. Comparison between the \% of nest-building in the experimental group where three males were held in the aquarium (number of aquarium $=8$ ) and the control group where one male was held in the aquarium (number of aquarium $=8$ ). Significant differences were found $\left(\mathrm{X}^{2}\right.$-Test, $\left.\mathrm{P}<0.05\right)$ between the experimental group (three males in the aquarium) and the control group (one male in the aquarium).

\section{$\%$ nest-building}

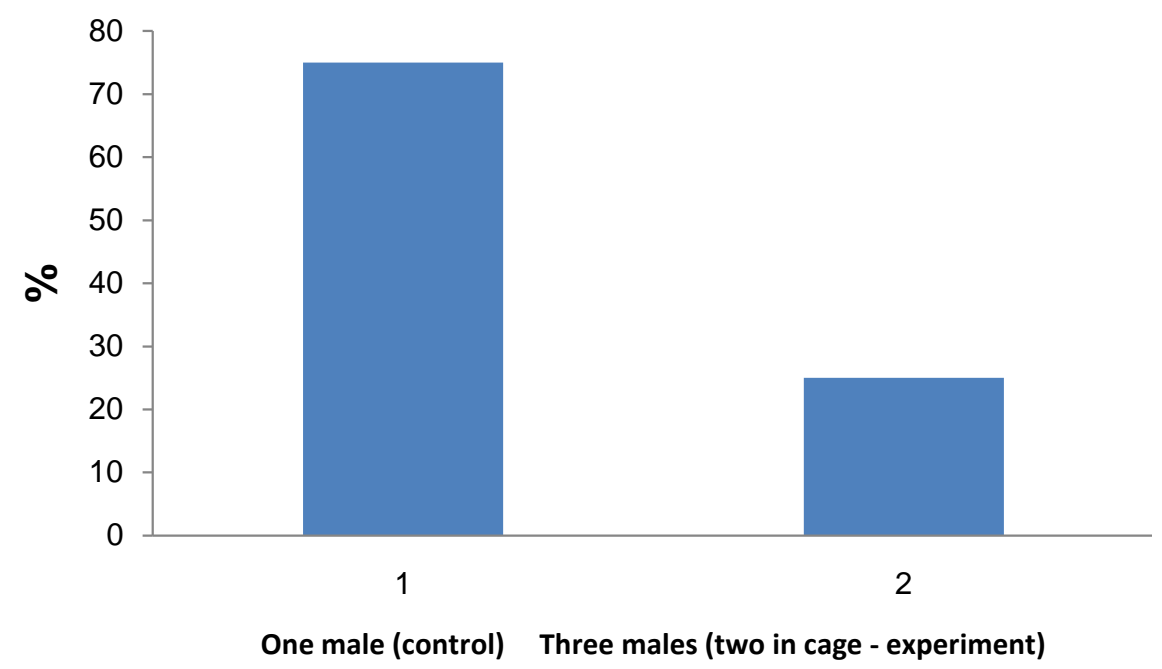

Figure 4. Comparison between the \% of nest-building in the experimental group where three males were held in the aquarium (number of aquarium $=8$ ) and two of them in the cage (Figure 1(d)) and the control group where one male was held in the aquarium (number of aquarium $=8$ ). Significant differences were found $\left(\mathrm{X}^{2}\right.$-Test) between the experimental (three male) and control groups. 


\section{$\%$ nest-building}

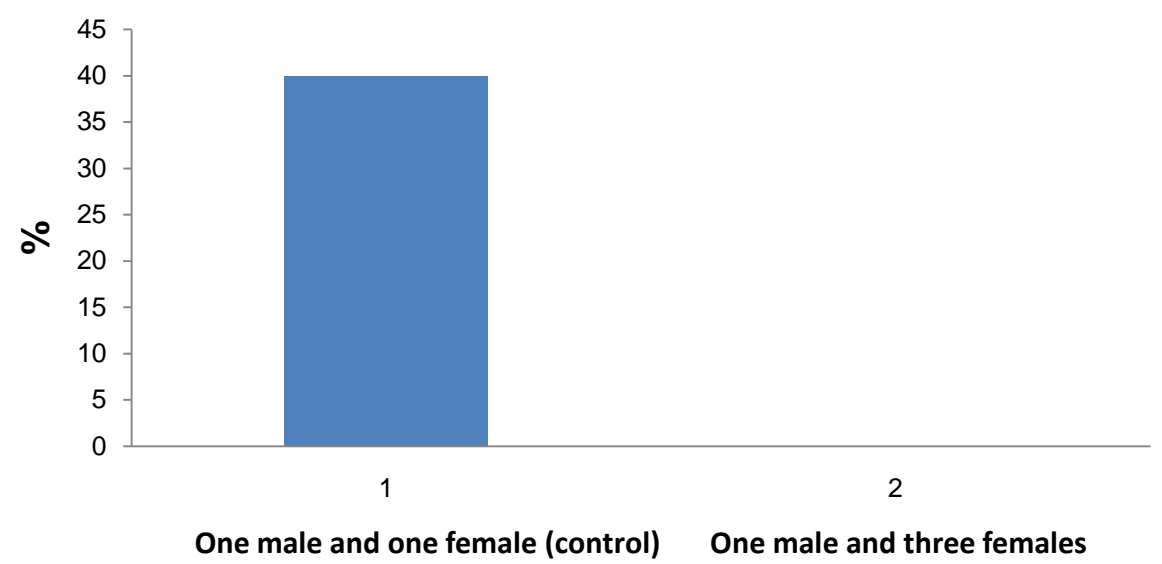

Figure 5. Comparison between the \% of nest-building in the experimental group where three females were held in the aquarium (number of aquarium $=8$ ) and one male and the control group where one male and one female were held in the aquarium (number of aquarium $=8)$.

\section{Discussion}

In this study, we support the well-known hypothesis that blue gourami requires territory in order to build nests [1], and that males found in the area of the territory are affected by other males as is sexual nest-building behavior [3] [5]. The contribution of the present study supports the hypothesis that not only the behavior of males or females in relatively high densities prevents nest-building but also that the pheromones of other males [13] reduces the number of nests built. Our suggestion for explaining this result is that the two males maintained in the cage in the same aquarium are affected only by the pheromones of one male in reducing the number of nests built, as is found in the present study. This result is supported by previous studies on the sexual behavior of blue gourami [6]-[9]. The aggressive male behavior enhancing the ability of male blue gourami to defend its territories was studied in detail [10]. The present study supports the hypothesis that the territories also prevent the effect of pheromones of other males on sexual behavior and nest-building. During reproduction, only the dominant male that has a territory builds nests. The territory sends away the other males and only the pheromones of the dominant male affect the female. The pheromones of male blue gourami affect female gametogensis and gonadotropin cells in the pituitary [13]-[16].

In summary, the present study and previous studies suggest that both aggressive behavior and pheromones affect interactions among males, and only the males that have territories preventing both factors are able to build nests.

\section{References}

[1] Degani, G. (2001) Blue Gourami (Trichogaster trichopterus) Model for Labyrinth Fish. Laser Pages Publishing, Israel, 134.

[2] Forselius, S. (1973) Studies on Anabantoid Fish. Zoologiska Bidrag Från Uppsala, 32, 93-589.

[3] Forselius, S. (1957) Studies of Anabantid Fishes. Zoologiska Bidrag Från Uppsala, 32, 593-597.

[4] Cole, B., Tamura, C.S. and Baile, R. (1999) A Manual for Commercial Production a Temporal Period Spawner. Vol. 135, Center of Tropical and Subtropical Aquaculture Publication, 1-32.

[5] Miller, J.R. (1964) Studies on the Social Behavior of the Blue Gourami, Trichogaster trichopterus (Pisces, Belontiidae). Copeia, 3, 469-496. http://dx.doi.org/10.2307/1441512

[6] Cheal, M. and Davis, R.E. (1974) Sexual Behavior: Social and Ecological Influences in the Anabantoid Fish, Trichogaster trichopterus. Behavioral Biology, 10, 435-445. http://dx.doi.org/10.1016/S0091-6773(74)92009-4

[7] Miller, M.R. and Robbins, M.E. (1954) The Reproductive Cycle in Taricha torosa (Triturus torosus). Journal of Experimental Biology, 215, 415-445. http://dx.doi.org/10.1002/jez.1401250304

[8] McKinnon, J. and Liley, N. (1986) Asymmetric Species in Response to Female Sexual Pheromones by Males of Two 
Species of Trichogaster (Pisces: Belontidae). Canadian Journal of Zoology, 65, 1129-1134. http://dx.doi.org/10.1139/z87-176

[9] Degani, G. (1989) The Effect of Temperature, Light, Fish Size and Container Size on Breeding of Trichogaster trichopterus. Israeli Journal of Aquaculture Bamidgeh, 41, 67-73.

[10] Hollis, K.L., Dumas, M.J., Singh, P. and College, P.F.M.H. (1995) Pavlovian Conditioning of Aggressive Behavior in Blue Gourami Fish (Trichogaster trichopterus): Winners Become Winners and Losers Stay Losers. Journal of Comparative Psychology, 109, 123-133. http://dx.doi.org/10.1037/0735-7036.109.2.123

[11] David, D. and Degani, G. (2011) Temperature Affects Brain and Pituitary Gene Expression Related to Reproduction and Growth in the Male Blue Gouramis, Trichogaster trichopterus. Journal of Experimental Zoology Part A: Ecological Genetics and Physiology, 315, 203-214. http://dx.doi.org/10.1002/jez.663

[12] Degani, G. and Levy, G. (2013) Underground Water Affects Sexual behavior and Gene Expression of Hormones Related to Reproduction in Blue Gourami Males. Advances in Biological Chemistry, 3, 133-140. http://dx.doi.org/10.4236/abc.2013.31016

[13] Becker, D., Galili, M. and Degani, G. (1992) GCNS-Identified Steroids and Steroids Goucoronides in Gonads and Holding Water in Gonads and Holding Water of Trichogaster tricopterus (Anabantidea, Pallas 1770). Comparative Biochemistry and Physiology, 103B, 15-19.

[14] Degani, G. and Schreibman, M.P. (1993) Pheromone of Males Bllue Gourami and Its Effect on Vitellogenesis and Gonadotropin Cells in Ptuitary of the Females. Journal of Fish Biology, 43, 475-485.

[15] Pollak, E.I. and Christian, J.J. (1977) Social Activation of the Interrenal Gland in the Blue Gourami, Trichogaster trichopterus (Pisces, Belontiidae). Behavioral Biology, 19, 217-227. http://dx.doi.org/10.1016/S0091-6773(77)91506-1

[16] Lee, C.T. and Ingersoll, D.W. (1979) Social Chemosignals in Five Belontiidae (Pisces) Species. Journal of Comparative Physiology, 93, 1171-1181.

\section{Submit or recommend next manuscript to SCIRP and we will provide best service for you:}

Accepting pre-submission inquiries through Email, Facebook, Linkedin, Twitter, etc A wide selection of journals (inclusive of 9 subjects, more than 200 journals)

Providing a 24-hour high-quality service

User-friendly online submission system

Fair and swift peer-review system

Efficient typesetting and proofreading procedure

Display of the result of downloads and visits, as well as the number of cited articles

Maximum dissemination of your research work

Submit your manuscript at: http://papersubmission.scirp.org/ 